CLINICAL STUDY

\title{
Should parafibromin staining replace HRTP2 gene analysis as an additional tool for histologic diagnosis of parathyroid carcinoma?
}

Filomena Cetani, Elena Ambrogini, Paolo Viacava ${ }^{1}$, Elena Pardi, Giovanni Fanelli ${ }^{1}$, Antonio Giuseppe Naccarato ${ }^{1}$, Simona Borsari, Monica Lemmi, Piero Berti ${ }^{2}$, Paolo Miccoli ${ }^{2}$, Aldo Pinchera and Claudio Marcocci

Departments of Endocrinology and Metabolism, ${ }^{1}$ Oncology, Section of Pathology and ${ }^{2}$ Surgery, University of Pisa, Pisa, Italy

(Correspondence should be addressed to F Cetani who is now at Department of Endocrinology and Metabolism, University of Pisa, Via Paradisa 2, 56124 Pisa, Italy; Email: cetani@endoc.med.unipi.it)

\begin{abstract}
Objective: HRPT2 gene mutations are associated with parathyroid carcinomas, and absence of parafibromin immunoreactivity has been suggested as a diagnostic marker of malignancy. The aim of our study was to extend parafibromin studies in a series of benign and malignant parathyroid tumors and cross-validate the results of immunohistochemistry with those of HRPT2 analysis.

Design and patients: We performed parafibromin and cyclin D1 immunostaining and HRPT2 gene analysis using loss of heterozygosity studies and sequencing analysis in parathyroid specimens from 11 patients with carcinoma (eleven primary tumors, one skin, and four lung metastases), 22 with sporadic adenomas, and 4 with atypical adenomas.

Results: Ten out of eleven parathyroid cancers were negative for parafibromin staining and showed HRPT2 gene abnormalities. The remaining sample was negative for immunostaining and genetic analyses. All but one sporadic adenomas showed parafibromin immunoreactivity and no HRPT2 gene abnormalities. The sample with negative immunostaining carried an HRPT2 mutation. Two atypical adenomas were positive and two negative with parafibromin staining. No HRPT2 abnormalities were found in these samples. Cyclin D1 expression was heterogeneous and there was no relationship between expression/expression level of cyclin D1 and parafibromin expression.

Conclusions: We have shown that negative parafibromin staining is almost invariably associated with HRPT2 mutations and confirm that loss of parafibromin staining strongly predicts parathyroid malignancy. In clinical practice, these tests could be particularly useful in the subset of parathyroid tumors with equivocal histological examination. However, their diagnostic value in this setting remains to be proven.
\end{abstract}

European Journal of Endocrinology 156 547-554

\section{Introduction}

Primary hyperparathyroidism (PHPT) is the most common cause of hypercalcemia in the general population and is caused in approximately $85 \%$ of cases by a single hyperfunctioning adenoma or, more rarely ( $<1 \%$ of cases), by a carcinoma (1).

The course of parathyroid carcinoma is rather indolent and it is common that the diagnosis of malignancy is made retrospectively following recurrence of the disease (2). Indeed, at initial parathyroidectomy, the diagnosis of malignancy can be established with certainty only in those tumors showing evidence of vascular invasion, perineural space invasion and growth into adjacent tissues or distant metastases (3). Other histological features characteristic of carcinoma, such as trabecular pattern, mitoses, thick fibrous bands and capsular invasion, may also be present in the so-called atypical adenoma and therefore cannot be considered diagnostic (4-6).

In recent years, several attempts have been made to identify a diagnostic marker of parathyroid malignancy (7-10). Loss of Rb1 protein immunostaining was shown to be a potentially useful diagnostic tool (7) but, because of subsequent contradictory results, this test is not routinely used in clinical practice.

The recent demonstration that the HRPT2 gene is involved in the pathogenesis of sporadic parathyroid cancer has raised the possibility that analysis of this gene might have some diagnostic utility (11-14). Parafibromin, the 531 amino acid protein encoded by the HRPT2 gene (15), is part of the human Paf1 complex and involved in transcription regulation, histone modification and cell proliferation (16-21). It has been shown that parafibromin down-regulates the expression of cyclin D1 $(16,20)$. The protein is mostly located in the 
nucleus and the nuclear localization signal (NLS) was originally identified at residues 125-139 (19) and most recently at residues 136-139 (21). Inactivating mutations of parafibromin were reported in $77 \%$ of sporadic parathyroid carcinomas (11-13) and loss of immunoreactivity for parafibromin was shown in the majority of parathyroid carcinomas $(22,23)$. Thus, parafibromin immunostaining, because of its lower cost and greater feasibility when compared with genetic analysis, could become a promising molecular marker for the diagnosis of parathyroid carcinoma.

The aim of the present study was to extend parafibromin immunostaining studies in a series of benign and malignant parathyroid tumors, and crossvalidate their results with those of HRPT2 gene analysis.

\section{Materials and methods}

\section{PHPT patients}

The study was approved by our Internal Review Board. All patients gave their informed consent for genetic studies.

The diagnosis of PHPT was based on increased total or ionized serum calcium $(>2.55$ and $>1.32 \mathrm{mmol} / \mathrm{l}$ respectively) and inappropriately elevated serum parathyroid hormone (PTH) levels (normal range $10-75 \mathrm{ng} / \mathrm{l})$.

Sporadic parathyroid carcinomas All patients had either local recurrence and/or distant metastases after initial parathyroid surgery. The clinical and genetic data of seven patients (nos 1-7) were previously reported (13). The remaining four patients (nos 8-11) are described in more detail herein (Table 1). Parathyroid cancer was diagnosed at the age of 45, 51, 56, and 52 years respectively. Patients underwent parathyroidectomy and later had evidence of either local recurrence $(n=2)$, cervical lymph node metastasis $(n=1)$, or multiple lung metastases $(n=3)$. The interval between initial surgery and the first recurrence ranged between 7 months and 4 years (mean 2 years). Various degrees of hypercalcemia developed during follow-up (maximum mean serum calcium $3.5 \mathrm{mmol} / \mathrm{l}$ ). No patient was treated with chemotherapy; two (nos 1, 10) received external neck irradiation and one (no. 8) a short treatment with cinacalcet. Intravenous pamidronate or zoledronate were used in most cases in an attempt to reduce the degree of hypercalcemia.

Sporadic parathyroid adenomas The clinical and genetic characteristics of these patients have previously been reported (13).

Atypical adenomas The clinical data of the four patients with sporadic PHPT with single-gland disease are reported in Table 1. All patients were submitted to parathyroidectomy and, with one exception, to total thyroidectomy (one for multinodular goiter (no. 2.1) and two for intrathyroidal parathyroid lesion (nos 2.3 and 2.5)). The histopathological evaluation showed the typical features of atypical adenomas, namely entrapment of tumor cells within the capsule, intratumoral

Table 1 Clinical data, HRPT2 gene analyses, and parafibromin immunostaining in parathyroid carcinomas and atypical adenomas ${ }^{\mathrm{a}}$.

\begin{tabular}{|c|c|c|c|c|c|c|c|c|}
\hline & Diagnosis & $\begin{array}{c}\text { Age at } \\
\text { diagnosis } \\
\text { (year/sex) }\end{array}$ & $\begin{array}{l}\text { Cystic } \\
\text { features }\end{array}$ & $\begin{array}{l}\text { HRPT2 } \\
\text { mutational status }\end{array}$ & $\begin{array}{l}\text { Effect on } \\
\text { parafibromin }\end{array}$ & $\begin{array}{l}\text { HRPT2 } \\
\text { mutation }\end{array}$ & $\begin{array}{c}\mathrm{LOH}^{\mathrm{c}} \\
\text { at } \\
\text { HRPT2 }\end{array}$ & $\begin{array}{l}\text { Parafibromin } \\
\text { immunoreactivity }^{\text {b }}\end{array}$ \\
\hline \multirow[t]{3}{*}{1} & Carcinoma & $43 / F$ & No & Wild type & - & - & Yes & Negative \\
\hline & Lung metastasis & & No & Wild type & - & - & Yes & Negative \\
\hline & Skin metastasis & & No & Wild type & - & - & Yes & Negative \\
\hline \multirow[t]{2}{*}{2} & Carcinoma & $32 / F$ & No & $700 \mathrm{C}>\mathrm{T}$ in exon $7^{\mathrm{d}}$ & Stop codon R234X & Germ line & No & Negative \\
\hline & Lung metastasis & & No & $700 \mathrm{C}>\mathrm{T}$ in exon 7 & Stop codon R234X & Germ line & No & Negative \\
\hline \multirow[t]{2}{*}{3} & Carcinoma & $53 / \mathrm{M}$ & No & 195ins T in exon 3 & Stop codon at 104 & Somatic & Yes & Negative \\
\hline & Lung metastasis & & No & 195insT in exon 3 & Stop codon at 104 & Somatic & Yes & Negative \\
\hline 4 & Carcinoma & $50 / \mathrm{M}$ & No & $25 \mathrm{C}>\mathrm{T}$ in exon 1 & Stop codon R9X & Somatic & Yes & Negative \\
\hline 5 & Carcinoma & $63 / \mathrm{M}$ & No & 195ins $A$ in exon 2 & Stop codon at 104 & Somatic & Yes & Negative \\
\hline 6 & Carcinoma & $36 / F$ & No & $25 \mathrm{C}>$ in exon $1 \mathrm{~T}$ & Stop codon R9X & Somatic & Yes & Negative \\
\hline \multirow[t]{2}{*}{7} & Carcinoma & $45 / \mathrm{M}$ & No & $700 \mathrm{C}>\mathrm{T}$ in exon $7^{\mathrm{d}}$ & Stop codon R234X & Germ line & Yes & Negative \\
\hline & Lung metastasis & & No & $700 \mathrm{C}>\mathrm{T}$ in exon 7 & Stop codon R234X & Germ line & Yes & Negative \\
\hline 8 & Carcinoma & $45 / \mathrm{M}$ & No & $70 \mathrm{G}>\mathrm{T}$ in exon 1 & Stop codon E24X & Somatic & Yes & Negative \\
\hline 9 & Carcinoma & $51 / F$ & No & $415 \mathrm{C}>\mathrm{T}$ in exon 5 & Stop codon R139X & Germ line & No & Negative \\
\hline 11 & Carcinoma & $52 / \mathrm{M}$ & No & $182 \mathrm{~T}>\mathrm{A}$ in exon 2 & Stop codon L61X & Somatic & No & Negative \\
\hline 2.1 & Atypical adenoma & $44 / \mathrm{M}$ & No & Wild type & - & - & No & Negative \\
\hline 2.2 & Atypical adenoma & $56 / \mathrm{M}$ & No & Wild type & - & - & No & Negative \\
\hline 2.3 & Atypical adenoma & $19 / \mathrm{M}$ & No & Wild type & - & - & No & Positive (20) \\
\hline 2.5 & Atypical adenoma & $48 / \mathrm{M}$ & No & Wild type & - & - & No & Positive (40) \\
\hline
\end{tabular}

${ }^{a}$ Clinical data and HRPT2 gene analyses of patients nos 1-7 have previously been reported (Ref. (13)).

${ }^{\mathrm{b}}$ Number in parentheses indicate the percentage of positive cells.

'Loss of heterozygosity.

dThese two patients, showing the same HRPT2 mutation, were unrelated. 
fibrosis, mitoses and fibrous bands, but lack of unequivocal signs of capsular or vascular invasion (5).

Follow-up after surgery ranged from 8 months to 3.2 years (mean 2 years). One patient (no. 2.5) was cured, one (no. 2.1) had permanent hypoparathyroidism treated with calcium and calcitriol, one (no. 2.2) had persistent PHPT, and one (no. 2.3) had moderately elevated PTH levels $(126 \mathrm{pg} / \mathrm{ml})$ with normocalcemia. None of the latter two showed abnormalities in the imaging studies (neck ultrasound, neck and lung CT scan, and sestamibi scan).

\section{Tissue samples}

Twenty-two parathyroid adenomas, four atypical adenomas, and sixteen cancer specimens (eleven primary tumors, one skin metastasis, and four lung metastases) were studied.

Tissues were obtained at the time of surgery, immediately snap frozen in liquid nitrogen, and stored at $-80{ }^{\circ} \mathrm{C}$ until use.

\section{Pathological findings}

All tumors were histologically defined according to the recent World Health Organization classification $(4,5)$.

All parathyroid specimens were carefully reviewed by two pathologists (PV and GF) in order to confirm the histological diagnosis by the use of homogeneous criteria, eventually describe the presence of cystic features, and check that all samples had a sufficient proportion of tumor cells for DNA analyses $(>70 \%)$.

\section{HRPT2 gene analyses}

Genomic DNA was isolated from peripheral blood leukocytes and parathyroid tissue by the standard proteinase K-SDS digestion and the phenol/chloroform method. Allelic deletions and direct sequencing of HRPT2 gene were assessed as described previously (13).

\section{Immunohistochemistry}

Archival sections were deparaffinized in xylene and rehydrated in alcohol. Endogenous peroxide activity was blocked by incubating the slides in $1 \%$ hydrogen peroxide in methanol for $10 \mathrm{~min}$. In order to unmask the antigen, the slides were microwave treated in $10 \mathrm{mM}$ citrate buffer ( $\mathrm{pH}$ 6.0) for $10 \mathrm{~min}$. After blocking nonspecific staining with normal serum, the sections were incubated for $1 \mathrm{~h}$ with the primary monoclonal antibody (MAb) used at the dilution ratio of 1:50. The parafibromin antibody (kindly donated by Bin Tean Teh) is directed against the portion of the protein corresponding to amino acid positions 87-100 (22). The cyclin D1 antibody (clone SP4) was from Lab Vision (Fremont, CA, USA). The sections were then incubated with biotin-labeled secondary antibody (dilution 1:500) and avidin-biotin complex (Vector Burlingame, Burlingame, CA, USA) for $30 \mathrm{~min}$ each. Sites of binding were visualized using 3,3-diaminobenzidine as the chromogen. Finally, sections were counterstained with hematoxylin, dehydrated, and mounted. The positive control was normal parathyroid tissue for parafibromin and a breast carcinoma overexpressing cyclin D1 for cyclin D1; negative controls included experiments omitting primary antibody or using primary antibody preabsorbed with a 20-fold excess of the immunizing peptide. For each case, six different sections were analyzed.

Tumors were scored as positive if specific nuclear staining was detected, and the staining was quantified according to the percentage of positive cells, independent of the intensity of staining. Tumors were scored as negative when no tumor cells showed a specific nuclear staining.

Each section was evaluated by two independent observers (PV and GF) without knowledge of the diagnosis or outcome. In cases where the assessment of percentage positivity differed between the two observers, the disagreements were resolved by reaching a consensus after joint review using a conference microscope.

\section{Statistical analysis}

Sensitivity, specificity, predictive values and 95\% confidence interval (CI) for proportions were calculated using standard methods for binomial distribution. The $\chi^{2}$ test, Fisher's exact test and the Mann-Whitney test were used as indicated.

\section{Results}

\section{HRPT2 gene analyses}

Results of loss of heterozygosity (LOH) and mutational analyses of the 22 adenomas and carcinomas specimens from patients nos 1-7 have previously been reported (13). We report herein the results observed in additional samples (four atypical adenomas and four carcinomas) (Table 1). All tissues were informative at least for one polymorphic site at $\mathrm{LOH}$ analysis and, with the exception of a cancer specimen, showed retention of heterozygosity. HRPT2 mutations resulting in a premature stop codon were found in three out of four carcinomas (Table 1); all atypical adenomas were negative. The HRPT2 mutations described here were not found in 50 unrelated normal individuals of Italian origin.

\section{Parafibromin immunohistochemistry}

In each experiment normal parathyroid gland tissue was used as the positive control and showed a diffuse nuclear staining. Immunoreactivity was highly specific for 
parathyroid chief cells, without staining of adipose or connective tissues or blood vessels (Fig. 1A). Controls with antibody, pre-absorbed with a 20-fold excess of specific peptide, did not show any immunoreactivity.

All parathyroid carcinomas and metastases were negative for parafibromin (Table 1; Fig. 1C and D). In one tumor a weak cytoplasmic signal was observed. In contrast, all but one parathyroid adenomas were parafibromin positive (Fig. 1B). Parafibromin expression was heterogeneous with a range of positive cells between 10 and $80 \%$. Immunoreactivity was not detected in the adenoma carrying an HRPT2 mutation (Fig. 1E).
Two atypical adenomas specimens were positive (patients nos 2.3 and 2.5; 20 and $40 \%$ of positive cells respectively) and two (nos 2.1 and 2.2) were negative (Table 1). A representative case is shown in Fig. 1F.

\section{Correlation between parafibromin immunostaining and HRPT2 gene alterations}

Status of parafibromin expression was compared with HRPT2 gene alterations (Tables 1 and 2 and Ref. (13)). Ten out of eleven parathyroid carcinomas, all negative for parafibromin immunostaining, showed HRPT2 gene
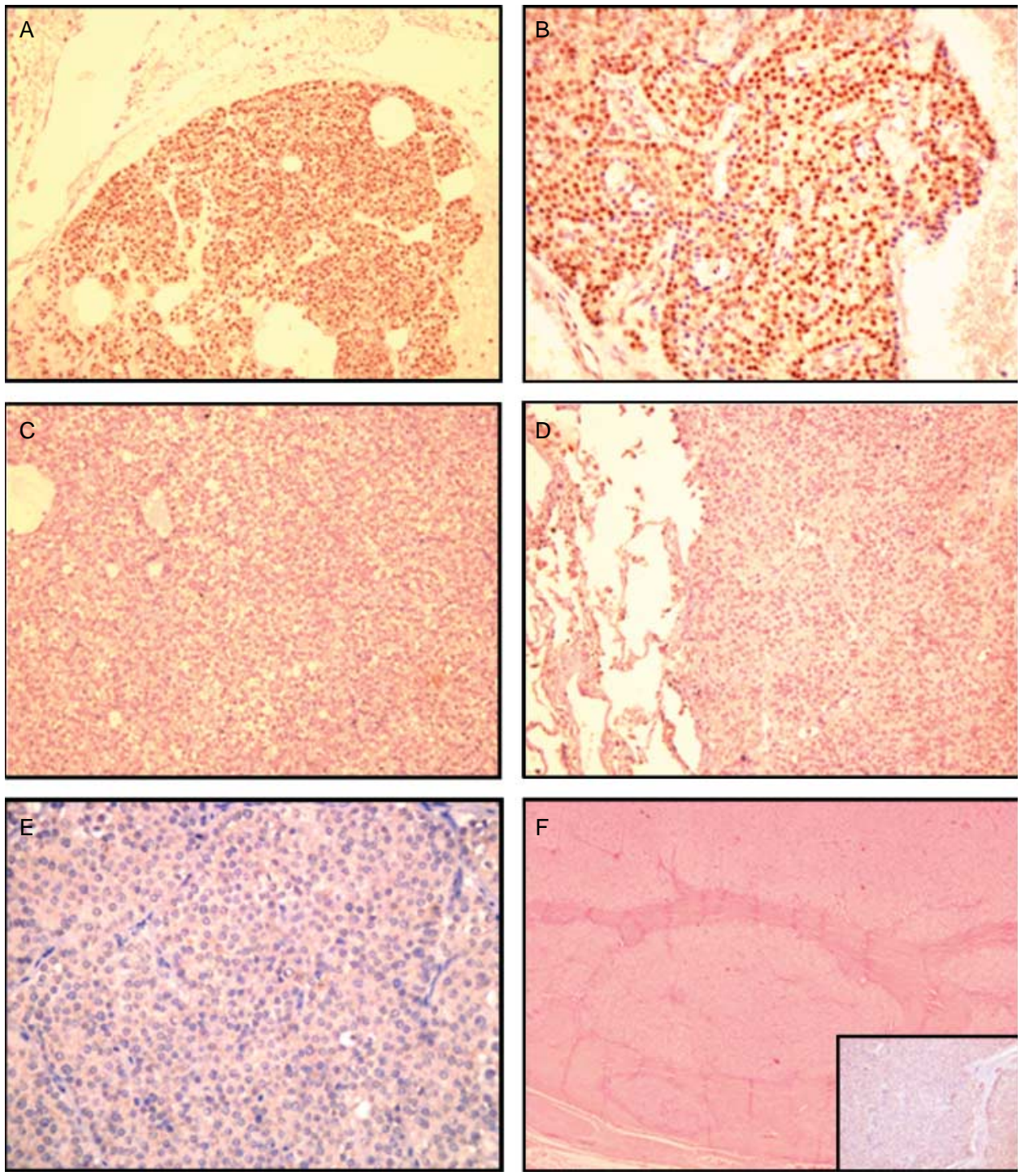

$\mathrm{F}$

Figure 1 Immunohistochemical analyses of parafibromin expression. A: Normal parathyroid gland. The parathyroid cells showed a diffuse nuclear immunoreactivity $(\times 200)$. B: Parathyroid adenoma. The majority of cells showed a nuclear immunoreactivity for parafibromin. Some nuclei were negative. C: Parathyroid carcinoma. The neoplastic cells were completely negative for parafibromin (X200). D: Lung metastasis of parathyroid carcinoma. The tumor showed a diffuse loss of staining. Adjacent lung parenchyma was also negative $(\times 200)$. $\mathrm{E}$ : Parathyroid adenoma carrying HRPT2 mutation. The tumor cells were completely negative for parafibromin $(\times 400)$. F: Atypical parathyroid adenoma (no. 2.1). The tumor showed sheets of neoplastic cells separated by fibrous bands. No invasion of the capsule was evident (hematoxylin-eosin, $\times 100)$. Inset shows that the cells were completely negative for parafibromin $(\times 200)$. 
Table 2 Diagnostic value (\%) of HRPT2 gene abnormalities for differentiating parathyroid carcinomas from adenomas (including atypical adenomas).

\begin{tabular}{lccc}
\hline & $\begin{array}{c}\text { Loss of parafibromin } \\
\text { immunostaining }\end{array}$ & HRPT2 mutation & $\begin{array}{c}\text { Loss of } \\
\text { heterozygosity }\end{array}$ \\
\hline Sensitivity $(95 \% \mathrm{Cl})$ & $100(68-100)$ & $82(48-97)$ & $64(32-88)$ \\
Specificity $(95 \% \mathrm{Cl})$ & $88(69-97)$ & $96(78-100)$ & $96(78-100)$ \\
Positive predictive value at $0.5 \%$ prevalence $(95 \% \mathrm{Cl})$ & $4(0-11)$ & $10(1-19)$ & $8(0-16)$ \\
Negative predictive value at $0.5 \%$ prevalence $(95 \% \mathrm{Cl})$ & $100(100-100)$ & $100(99-100)$ & $100(98-100)$ \\
Positive predictive value at 5\% prevalence $(95 \% \mathrm{Cl})$ & $31(16-46)$ & $53(37-69)$ & $46(30-63)$ \\
Negative predictive value at 5\% prevalence $(95 \% \mathrm{Cl})$ & $100(100-100)$ & $100(96-100)$ & $98(94-100)$ \\
\hline
\end{tabular}

abnormalities (mutations in nine cases, associated $(n=6)$ or not $(n=3)$ with $\mathrm{LOH}$, and $\mathrm{LOH}$ alone in one case). The remaining sample was negative at immunostaining and genetic analyses.

All but one adenoma showed parafibromin immunoreactivity and no HRPT2 gene abnormalities were detected in these samples. The tumor with negative immunostaining carried an HRPT2 mutation.

As mentioned before, all mutations generated premature stop codons which are predicted to cause truncated proteins of different size. Figure 2 depicts a schematic representation of parafibromin, including the binding site of the MAb used in the present study, the NLS of the protein (19), and the truncated proteins resulting from the HRPT2 mutations detected in our tumor series. Six mutations (R9X, E24X, IVS1 + 1G >A, L61X, 195insA, and 195insT) were located in the N-terminal part of the protein before the antibody-binding site. Thus, the resulting truncated proteins do not contain either the amino acid sequence recognized by the antibody or the NLS. The R139X mutation was located just at the end of the C-terminal arm of the NLS, and the R234X far downstream with respect to either the antibody-binding site or the NLS. Therefore, in both cases, the altered proteins included the antibody-binding site and the NLS.

Two atypical adenomas were positive and two negative at immunohistochemistry. No LOH or HRPT2 mutations were found in these.
In summary, 11 out of 14 cases (ten carcinomas and one adenoma) showed an association between the loss of parafibromin staining and the HRPT2 gene abnormalities, whereas no gene alteration was detected in three cases (one carcinoma and two atypical adenomas). On the other hand, parafibromin expression was associated in all cases with normal HRPT2 gene analysis (21 sporadic and 2 atypical adenomas $(P<0.0001$ by Fisher's exact test)).

\section{Diagnostic values of HRPT2 gene abnormalities}

The diagnostic values of HRPT2 gene abnormalities for differentiating parathyroid carcinoma from adenoma are shown in Table 2. Loss of parafibromin staining had a sensitivity of $100 \%$, greater than that of HRPT2 mutation and LOH; on the other hand, the latter two tests had a greater specificity when compared with immunostaining. It is commonly estimated that parathyroid cancer accounts for $<1 \%$ of cases of sporadic PHPT. At our institution, the prevalence of parathyroid cancer is $0.5 \%$ (3 out of 555 consecutive patients with sporadic PHPT submitted to parathyroidectomy over the last 8 years). A higher prevalence (5\%) has been reported by another Italian group in 290 PHPT patients submitted to surgery between 1980 and 1996 (24). We have no explanation for such a discrepancy. The positive



Figure 2 Schematic of fulllength and truncated parafibromin. The binding site of the monoclonal antibody used in the present study (dashed box) and the nuclear localization signal (dotted box) are shown. 
predictive values (PPV) and negative predictive values (NPV), with 95\% CI, for an estimated prevalence of 0.5 and $5 \%$ of cancer among patients with PHPT, are also reported in Table 2 .

\section{Relationship between cyclin $D 1$ expression and parafibromin expression}

Cyclin D1 expression was heterogeneous with a range of positive cells between 1 and $80 \%$ and was graded on the following scale: mild (1-10\% positive nuclei), moderate (11-30\% positive nuclei), and strong $(>30 \%$ positive nuclei). There was no relationship between expression/ level of expression of cyclin D1 and parafibromin expression (Table 3) or HRPT2 gene alterations (data not shown).

\section{Discussion}

The aim of the present study was to further validate the use of parafibromin staining in the diagnosis of parathyroid malignancy, by comparing immunohistochemistry results and HRTP2 genetic analysis in a series of benign and malignant parathyroid tumors. Twentyone out of twenty-two sporadic adenomas and two out of four atypical adenomas showed parafibromin immunoreactivity. All carcinomas, one adenoma and the remaining two atypical adenomas were negative at immunostaining. Thus, we confirm that loss of parafibromin staining strongly predicts malignancy.

With the exception of three cases (one carcinoma and two atypical adenomas), all parafibromin negative samples showed HRPT2 abnormalities, responsible for the synthesis of differently truncated proteins. Lack of the antibody-binding site could account for the negative immunostaining results in five cases. In the remaining six, the HRPT2 abnormalities were located downstream to the antibody-binding sequence and therefore the negative staining might be due to a less antigenic or a less stable mutated protein.

The combined evaluation of parafibromin expression and HRTP2 gene analysis was previously carried out in a
56 parathyroid tumors (41 sporadic adenomas (25), 2 sporadic carcinomas (23), and 13 hyperparathyroidismjaw tumor adenomas $(22,23))$. Parafibromin staining was negative in 16 out of 19 samples carrying HRPT2 mutations (all carcinomas and HPT-JT adenomas, and four adenomas). All the remaining samples (37 adenomas) showed positive parafibromin staining and absence of HRPT2 gene alterations. This data together with our results indicate that negative parafibromin staining is almost invariably associated with HRPT2 mutations (27 out of 30 cases, $90 \%$ ) and positive staining with no HRPT2 alterations (60 out of 63 cases, 95\%). Only a minority of cases ( 6 of a total of 93 studied) showed discrepant results (parafibromin staining in the presence of HRPT2 alterations or vice versa). In three cases (present study), the finding of negative parafibromin staining in the absence of abnormalities in the HRPT 2 coding and splice site regions could be explained by the occurrence of still unidentified mutations in the promoter or other regulatory regions of the gene, or alterations in the posttranscriptional processing of parafibromin with loss of immunoreactivity. On the other hand, missense mutations could explain retained parafibromin staining in two out of the three tumors reported by other authors. As discussed by Gill (23), missense mutations result in the production of a full-length parafibromin, which is still recognized by the antibody but is presumably less biologically active.

It could be argued that the two atypical parathyroid adenomas with negative parafibromin immunostaining and no HRPT2 gene abnormalities might have been misdiagnosed and be early stage parathyroid cancers. Indeed, loss of parafibromin not associated with HRPT2 gene abnormalities was observed in one of our carcinomas. This hypothesis is not supported by the follow-up, showing no evidence of local recurrence or distant metastasis after 33 and 44 months.

As mentioned before, all but one of the adenomas we studied were negative at HRPT2 gene analysis, thus confirming the low frequency of HRPT2 gene abnormalities in sporadic parathyroid adenomas (12-13, 15, 25-27). The association in this adenoma of a negative parafibromin staining prompted us to re-evaluate

Table 3 Relationship between parafibromin expression and cyclin D1 expression ${ }^{\mathrm{a}}$.

\begin{tabular}{|c|c|c|c|c|c|c|c|c|}
\hline \multirow[b]{3}{*}{ Cyclin D1 staining ${ }^{a}$} & \multirow{2}{*}{\multicolumn{2}{|c|}{$\begin{array}{l}\text { Adenomas }(n=22) \\
\text { Parafibromin staining }\end{array}$}} & \multirow{2}{*}{\multicolumn{2}{|c|}{$\frac{\text { Atypical adenomas }(n=4)}{\text { Parafibromin staining }}$}} & \multirow{2}{*}{\multicolumn{2}{|c|}{$\begin{array}{l}\text { Carcinomas }(n=11) \\
\text { Parafibromin staining }\end{array}$}} & \multirow{2}{*}{\multicolumn{2}{|c|}{$\frac{\text { Total }^{\mathrm{b}}(n=37)}{\text { Parafibromin staining }}$}} \\
\hline & & & & & & & & \\
\hline & Positive & Negative & Positive & Negative & Positive & Negative & Positive & Negative \\
\hline Negative & 13 & 1 & 1 & 1 & - & 3 & 14 & 5 \\
\hline Mild (1-10) & 3 & - & - & - & - & 3 & 3 & 3 \\
\hline Moderate (11-30) & 3 & - & - & - & - & 3 & 3 & 3 \\
\hline
\end{tabular}

${ }^{a}$ Number in parentheses indicates the percentage of positive cells.

${ }^{b}$ Statistical analysis was performed in the whole series of parathyroid tumors: (i) $P=0.244$ (by $\chi^{2}$ test). (ii) $P=0.183$ (by Fisher's exact test after grouping together all samples with cyclin D1 positive cells); (iii) $P=0.23$ (by Mann-Whitney test using individual percentages of cells positive for cyclin D1 expression). 
the histology. No features commonly observed in malignant lesions were found. The benign nature of this adenoma was also suggested by the long-term remission of PHPT.

In vitro studies have shown that parafibromin down regulates cyclin D1 expression. Our data show that both high and low level of cyclin D1 expression were found in malignant and benign parathyroid tumors, independent of the HRPT2 mutational status, indicating that other mechanisms are involved in the control of cyclin D1 expression in parathyroid cells. Similar results have recently been reported by Juhlin et al. in parathyroid adenomas (25).

The clinical utility of a diagnostic test depends on the prevalence of a disease in a given population, as well as the sensitivity and specificity. Given the rarity of parathyroid carcinoma $(0.5 \%$ of all cases of PHPT in our series), loss of parafibromin staining, as well as HRPT2 gene abnormalities, has a rather low PPV and therefore these both tests are not recommended for analysis of all parathyroid tumors, but would be most applicable to a subset of tumors with atypical features. Limiting these diagnostic tests to this subset will increase the PPV. However, because of the limited number of atypical adenomas no definite indication can be provided, even though the genetic analysis seems to have a better diagnostic accuracy. All tests showed an NPV of $100 \%$ but, based on our results, only the presence of parafibromin staining excludes malignancy (95\% CI, 100-100). This conclusion cannot be generalized since three carcinomas described by Gill showed a positive staining (23).

Parafibromin antibodies are commercially available and therefore parafibromin immunostaining, being cheaper and less time consuming when compared with HRPT2 genetic analysis, is expected to become widely used in cases which pose diagnostic challenges. The question of whether it should be preferred to genetic analysis can only be answered by studies including a greater number of equivocal parathyroid tumors.

\section{Acknowledgements}

We would like to thank Dr Bin Tean Teh, Van Andel Research Institute, Grand Rapids, Michigan, USA, for the generous gift of the monoclonal parafibromin antibody. We also thank Prof. Stefano Mariotti, Endocrinology Unit, Department of Medical Sciences, Presidio di Monserrato, University of Cagliari, Cagliari, Italy, for referring a patient with parathyroid carcinoma, Dr Maria Laura Manca, Department of Neuroscience, University of Pisa, Pisa, Italy for his statistical analysis assistance and Pasquale Cofelice of our Department for his technical assistance. We also thank the patients who graciously agreed to participate in the study.

\section{Funding}

This work was supported by grants from the University of Pisa (Fondi di Ateneo per la Ricerca) and the Ministero dell'Istruzione, dell'Università e della Ricerca (Project: Studies of new oncogenes involved in parathyroid tumorigenesis).

\section{References}

1 Marx SJ. Hyperparathyroidim and hypoparathyroid disorders. New England Journal of Medicine 2000343 1863-1875.

2 Shane E. Clinical review 122: parathyroid carcinoma. Journal of Clinical Endocrinology and Metabolism 20012 485-493.

3 De Lellis RA. Parathyroid carcinoma. An overview. Advances in Anatomic Pathology 200512 53-61.

4 Bondenson L, Grimelius L, DeLellis RA, Lloyd R, Akerstrom G, Larsson C, Arnold A, Eng C, Shane E \& Bilezikian JP. Parathyroid carcinoma. In Pathology and Genetics. Tumours of Endocrine Organs. WHO Classification of Tumours, pp 124-127. Eds. RA DeLellis, RV Lloyd, PU Heitz \& C Eng. Lyon: IARC Press, 2004.

5 Grimelius L, DeLellis RA, Bondenson L, Akerstrom G, Larsson C, Arnold A, Franssila KO, Hendy GN, Depuy D \& Eng C. Parathyroid adenoma. In Pathology and Genetics. Tumours of Endocrine Organs. WHO Classification of Tumours, pp 128-132. Eds. RA DeLellis, RV Lloyd, PU Heitz \& C Eng, Lyon: IARC Press, 2004.

6 Shantz A \& Castleman B. Parathyroid carcinoma. A study of 70 cases. Cancer 197331 600-605.

7 Cryns VL, Thor A, Xu HJ, Hu SX, Wierman ME, Vickery AL Jr, Benedict WF \& Arnold A. Loss of the retinoblastoma tumorsuppressor gene in parathyroid carcinoma. New England Journal of Medicine 1994330 757-761.

8 Dotzenrath C, Teh T, Farnebo F, Cupisti K, Svensson A, Toell A, Goretzki P \& Larsson C. Allelic loss of the retinoblastoma tumor suppressor gene: a marker for aggressive parathyroid tumors? Journal of Clinical Endocrinology and Metabolism 19968 3194-3196.

9 Cetani F, Pardi E, Viacava P, Dipollina G, Fanelli G, Picone A, Borsari S, Gazzerro E, Miccoli P, Berti P, Pinchera A \& Marcocci C. A reappraisal of the Rb1 gene abnormalities in the diagnosis of parathyroid cancer. Clinical Endocrinology 200460 99-106.

10 Shattuck TM, Kim TS, Costa J, Yandell DW, Imanishi Y, Palanisamy N, Gaz RD, Shoback D, Clark OH, Monchik JM, Wierman ME, Hollenberg A, Tojo K, Chaganti RS \& Arnold A. Mutational analyses of $\mathrm{RB}$ and $\mathrm{BRCA} 2$ as candidate tumour suppressor genes in parathyroid carcinoma. Clinical Endocrinology 200359 180-189.

11 Shattuck TM, Valimaki S, Obara T, Gaz RD, Clark OH, Shoback D, Wierman ME, Tojo K, Robbins CM, Carpten JD, Farnebo LO, Larsson C \& Arnold A. Somatic and germ-line mutations of the HRPT2 gene in sporadic parathyroid carcinoma. New England Journal of Medicine $2003 \mathbf{3 4 9} 1722-1729$.

12 Howell VM, Haven CJ, Kahnoski K, Khoo SK, Petillo D, Chen J, Fleuren GJ, Robinson BG, Delbridge LW, Philips J, Nelson AE, Krause U, Hammje K, Dralle H, Hoang-Vu C, Gimm O, Marsh DJ, Morreau H \& The BT. HRPT2 mutations are associated with malignancy in sporadic parathyroid tumours. Journal of Medical Genetics $200340657-663$.

13 Cetani F, Pardi E, Borsari S, Viacava P, Dipollina G, Cianferotti L, Ambrogini E, Gazzerro E, Colussi G, Berti P, Miccoli P, Pinchera A \& Marcocci C. Genetic analyses of the HRPT2 gene in primary hyperparathyroidism: germline and somatic mutations in familial and sporadic parathyroid tumors. Journal of Clinical Endocrinology and Metabolism 200489 5583-5591.

14 Rubin MR \& Silverberg SJ. Editorial: HRPT2 in parathyroid cancer: a piece of the puzzle. Journal of Clinical Endocrinology and Metabolism 200590 5505-5507. 
15 Carpten JD, Robbins CM, Villablanca A, Forsberg L, Presciuttini S, Bailey-Wilson J, Simonds WF, Gillanders EM, Kennedy AM, Chen JD, Agarwal SK, Sood R, Jones MP, Moses TY, Haven C, Petillo D, Leotlela PD, Harding B, Cameron D, Pannett AA, Hoog A, Heath H III, James-Newton LA, Robinson B, Zarbo RJ, Cavaco BM, Wassif W, Perrier ND, Rosen IB, Kristoffersson U, Turnpenny PD, Farnebo LO, Besser GM, Jackson CE, Morreau H, Trent JM, Thakker RV, Marx SJ, The BT, Larsson C \& Hobbs MR. HRPT2, encoding parafibromin, is mutated in hyperparathyroidism-jaw tumors syndrome. Nature Genetics 200232 676-680.

16 Woodard GE, Lin L, Zhang JH, Agarwal SK, Marx SJ \& Simonds WF. Parafibromin, product of the hyperparathyroidismjaw tumor syndrome gene HRPT2, regulates cyclin D1/PRAD1 expression. Oncogene 200424 1272-1276.

17 Yart A, Gstaiger M, Wirbelauer C, Pecnik M, Anastasiou D, Hess D \& Krek W. The HRPT2 tumor suppressor gene product parafibromin associates with human PAF1 and RNA polymerase II. Molecular and Cellular Biology 200525 5052-5060.

18 Rozenblatt-Rosen O, Hughes CM, Nannepaga SJ, Shanmugam KS, Copeland TD, Guszczynski T, Resau JH \& Meyerson M. The parafibromin tumor suppressor protein is part of a human Paf1 complex. Molecular and Cellular Biology 200525 612-620.

19 Hahn MH \& Marsh DJ. Identification of a functional bipartite nuclear localization signal in the tumor suppressor parafibromin. Oncogene 200524 6241-6248.

20 Zhao J, Yart A, Frigerio S, Perren A, Schraml P, Weisstanner C, Stallmach T, Krek W \& Moch H. Sporadic human renal tumors display frequent allelic imbalances and novel mutations of the HRPT2 gene. Oncogene (Nov 27; Epub ahead of print).

21 Bradley KJ, Bowl MR, Williams SE, Ahmad BN, Partridge CJ, Patmanidi AL, Kennedy AM, Loh NY \& Thakker RV. Parafibromin is a nuclear protein with a functional monopartite nuclear localization signal. Oncogene 200726 1213-1221.
22 Tan MH, Morrison C, Wang P, Yang X, Haven CJ, Zhang C, Zhao P, Tretiakova MS, Korpi-Hyovalti E, Burgess JR, Soo KC, Cheah WK, Cao B, Resau J, Morreau H \& Teh BT. Loss of parafibromin immunoreactivity is a distinguishing feature of parathyroid carcinoma. Clinical Cancer Research 200410 6629-6637.

23 Gill AJ, Clarkson A, Gimm O, Keil J, Dralle H, Howell VM \& Marsh DJ. Loss of nuclear expression of parafibromin distinguishes parathyroid carcinomas and hyperparathyroidism-jaw tumor (HPT-JT) syndrome-related adenomas from sporadic parathyroid adenomas and hyperplasias. American Journal of Surgical Pathology 200630 1140-1149.

24 Favia G, Lumachi F, Polistina F \& D’Amico DF. Parathyroid carcinoma: sixteen new cases and suggestions for correct management. World Journal of Surgery 199822 1225-1230.

25 Juhlin C, Larsson C, Yakoleva T, Leibiger I, Leibiger B, Alimov A, Weber G, Hoog A \& Villablanca A. Loss of parafibromin expression in a subset of parathyroid adenomas. Endocrine-Related Cancer 200613 509-523.

26 Krebs LJ, Shattuck TM \& Arnold A. HRPT2 mutational analysis of typical sporadic parathyroid adenomas. Journal of Clinical Endocrinology and Metabolism 200590 5015-5017.

27 Bradley KJ, Cavaco BM, Bowl MR, Harding B, Cranston T, Fratter C, Besser GM, Conceicao Pereira M, Davie MW, Dudley N, Leite V, Sadler GP, Seller A \& Thakker RV. Parafibromin mutations in hereditary hyperparathyroidism syndromes and parathyroid tumours. Clinical Endocrinology 200664 299-306.

Received 3 December 2006

Accepted 5 February 2007 